\title{
POLITIK PEMBANGUNAN INDONESIA CENTRIS SATU PERUBAHAN MENDASAR BAGI PENINGKATAN KESEJAHTERAAN RAKYAT
}

\author{
Suwandi \\ Universitas Pancasakti Tegal \\ suwandif4@gmail.com
}

\begin{abstract}
This research has objective to described political development in indonesia and the process of the funding for. Renewing and innovation is part of identity the nation to escape from dependence and interfering the hands of the people alien to independence .Human development completely, good born and inner, performed with balanced, so that the state of having strength in face the challenges, obstacles, and disorders coming from outside. By a mood of safe, the government can do development by baik.namun, still there is a shortage of and the advantage, during which time, development is centered in java, so that the economic growth also centralized in Java Island. A prosperity and welfare will be fulfilled when every citizen indonesia participated in development, so that changes the pattern and lifestyle that so far disadvantaged and can see positive change from the development. Innovation and updating very required to change road map develop indonesia sustainable to stay mengedepankan and respect local genius.
\end{abstract}

\section{Pendahuluan}

Kemerdekaan Bangsa Indonesia pada 17 Agustus 1945 bukanlah sesuatu yang diraih dengan tiba-tiba, tetapi melalui proses panjang yang dilakukan oleh rakyat bersama-sama dengan Tentara Nasional Indonesia (TNI) dengan cara bergerilya maupun penyerangan secara nyata. Kemerdekaan merupakan tonggak sejarah dari suatu bangsa untuk menentukan nasibnya sendiri tanpa campur tangan bangsa lain, termasuk bekas penjajah. Kemerdekaan bisa menentukan arah bangsa menuju kemakuran dan kesejahteran bagi rakyatnya. Jangan sampai kemerdekaan yang diraih dengan pengorbanan harta dan nyawa menjadi sia-sia, serta tidak memiliki nilai yang dapat dibanggakan. Oleh karena itu, bangsa yang merdeka harus melakukan perubahan-perubahan mendasar yang bisa meningkatkan kemajuan di bidang pendidikan, kesehatan, ekonomi, politik, budaya, maupun teknologi.

Kemajuan suatu bangsa dapat diukur dari kemampuan rakyatnya dalam menentukan nasibnya sendiri tanpa dibayang-bayangi intervensi oleh bangsa lain. Ideologi dan jatidiri dari bangsa yang merdeka memiliki keutamaan dan kebersamaan dalam memajukan bangsanya untuk lebih baik di masa depan. Bangsa yang maju adalah bangsa yang bijak dan menghormati semua pengorbanan yang dilakukan oleh para pendahulu dan pemimpinnya dalam membebaskan dari belenggu penjajahan. Penjajahan adalah bentuk imperialisme dan merupakan kejahatan terhadap kemanusiaan dan bertentangan dengan hak asasi manusia (HAM). Dengan 
mengingat betapa mulia pengorbanan yang telah dilakukan oleh para pahlawan, maka kita sepatutnya memiliki pola yang jelas dan terarah dalam membuat pembaharuan untuk memajukan bangsa. Pembaharuan yang dilakukan harus menitikberatkan pada kesamaan pandangan dan semangat nasionalis yang terpatri demi mewujudkan bangsa yang adil dan makmur.

Pembaharuan dan inovasi adalah bagian dari jatidiri bangsa untuk melepaskan diri dari ketergantungan dan campur tangan bangsa asing terhadap kemandirian. Persatuan dan kesatuan bangsa yang majemuk bisa menjadi kuat dan tidak tercabik-cabik oleh bangsa lain manakala bingkai yang mengikatnya kuat dan dijaga oleh kebersamaan dalam kebhinekaan. Bangsa yang besar adalah bangsa yang menghormati jasa para pahlawannya, sehingga semangat kejuangan yang ditinggalkan tetap dijalankan dengan benar, meskipun dalam realitasnya, generasi yang lebih muda sudah hampir pudar semangat dan jiwa kepahlawanannya.

\section{Pertanyaan}

\section{Apakah politik pembangunan Indo- nesia Centris akan berhasil? Bagaimana pendanaannya?}

\section{Pembahasan}

Dalam sejarah bangsa Indonesia, pemerintah selalu melakukan pembangunan dengan pola mengedepankan ekonomi sebagai titik tolak dalam menyejahterakan rakyatnya. Namun, tidak dipungkiri bahwa untuk melakukan pembangunan ekonomi dengan baik, maka kondisi politik dan keamanan yang stabil harus menjadi landasan utama, sehingga tidak ada gangguan dan hambatan yang bisa mengurangi laju pertumbuhan ekonomi. Sejarah memberikan inspirasi bahwa tanpa politik dan keamanan yang tangguh tidak mudah melakukan pembangunan dengan baik dan berkesinambungan. Pada jaman Orde Lama di mana kondisi politik tidak stabil, suasana politik tidak mendukung, seperti halnya negara-negara lain yang baru merdeka, Indonesia menghadapi masalah yang terkait dengan sistem politiknya yang belum berjalan baik dan proses pemantapan ikatan kebangsaannya yang belum tuntas (Budiono, 2016). Perekonomian sungguh sangat buruk, di mana hutang-hutang sangat banyak dan harus menjalankan beban ekonomi hasil Konferensi Meja Bundar (KMB) yang sangat memberatkan. Di samping itu, sistem demokrasi parlementer ternyata tidak menghasilkan pemerintahan yang stabil, karena kabinet jatuh bangun dan silih berganti. Akhirnya, bangsa Indonesia tidak bisa melakukan apa-apa dan tidak ada pembangunan yang bermakna. Bahkan, bisa dikatakan negara gagal untuk memakmurkan rakyatnya. Inilah fakta yang terjadi pada saat Orde Lama yang kemudian tumbang.

Dengan dilantiknya Jenderal Soeharto menjadi Presiden Indonesia yang kedua, maka kebijakan yang diambil menitikberatkan pada stabilitas politik dan keamanan agar pemerintah bisa melakukan pembangunan dengan terencana. Masa pemerintahan Soeharto yang dikenal dengan istilah Orde Baru yang melakukan perubahan dan pembaharuan dengan cara menyederhanakan jumlah partai politik dan mengejawantahkan program-program pembangunan yang dikenal dengan nama Recana Pembangunan Lima Tahun (Repelita) dan Trilogi Pembangunan. Repelita bisa dilakukan dengan baik dan Indonesia menjadi negara berkembang yang menuju negara maju dengan melalui pertumbuhan ekonomi yang berkelanjutan. Indonesia bahkan bisa melakukan swasembada pangan pada tahun 1985 dan disegani oleh negara- 
negara lainnya sebagai "Macan Asia". Pembangunan ekonomi yang maju pesat menjadikan bangsa dan rakyat Indonesia mengalami perbaikan ekonomi dan lingkungan yang aman, sehingga rakyat tidak takut dalam melakukan kegiatankegiatan ekonomi, karena keamanan dijamin pemerintah. Kebijakan pembangunan yang diterapkan pemerintah pada masa itu telah dianalisis dengan baik, sehingga substansi dan dampak dari kebijakan-kebijakan tersebut sudah diperhitungkan tanpa ada pretensi untuk menyetujui maupun menolaknya (Winarno, 2014:34).

Pembangunan manusia seutuhnya, baik lahir maupun batin, dilakukan dengan seimbang, sehingga negara memiliki kekuatan dalam menghadapi tantangan, hambatan, dan gangguan yang datang dari luar. Penyederhaan jumlah partai menjadi hanya dua, ditambah dengan Golongan Karya, merupakan teknik tersendiri di bidang politik guna mewujudkan masyarakat yang sejahtera. Di samping itu, terdapat Program Keluarga Berencana dan Transmigrasi yang dilakukan secara masif di seluruh tanahair untuk mengendalikan pertumbuhan dan penyebaran penduduk.

Dengan suasana aman, pemerintah dapat melakukan pembangunan dengan baik. Namun, masih terdapat kekurangan dan kelebihannya, di mana pada saat itu, pembangunan masih dipusatkan di Pulau Jawa, sehingga pertumbuhan ekonomi juga terpusat di Pulau Jawa. Banyak masyarakat juga terkumpul di Pulau Jawa, terutama di Jakarta. Kebijakan demikian senantiasa mengandung dampak negatif maupun positif, sehingga diperlukan kearifan dan pemahaman yang mendalam mengenai nilai, arah, program, dan strategi yang sesuai dengan sifat dan dasar dari perubahan itu sendiri (Martono, 2014:26). Di samping itu, penerapan kebijakan akan memiliki dampak atas kelompok sasaran atau lingkungan, dampak atas kelompok lain, dan dampak atas masa depan (Dye, 1981:367). Kebijakan pembangunan yang terpusat memunculkan berbagai permasalahan di kemudian hari dan harus dibenahi secara menyeluruh.

Pembanguan yang dipusatkan di Jawa bisa menimbulkan kecemburuan dan disharmoni di antara pulau yang satu dengan pulau yang lain dan timbul perasaan ketidakadilan sebagai rakyat Indonesia. Begitu juga pembangunan yang dilakukan pada masa reformasi di bawah kepemimpinan Presiden Susilo Bambang Yudhoyono. Meskipun Otonomi Daerah sudah mulai dijalankan di kabupaten/kota, namun masih terdapat ketimpangan dalam pelaksanaannya. Terjadi pula penambahan jumlah partai politik hingga sepuluh, serta pemilihan presiden secara langsung untuk pertama kalinya. Pemilihan DPR, DPD, dan DPRD juga dilakukan secara langsung dengan sistem terbuka yang menjadikan Indonesia sebagai negara demokrasi terbesar ketiga di dunia.

Pembangunan yang dilakukan di masa pemerintahan Presiden Joko Widodo dengan Nawacita sebagai janji kampanyenya mulai melakukan perubahan kebijakan dan inovasi yang bisa dirasakan oleh masyarakat luas, yang sebelumnya luput. Mimpi besar yang bakal terwujud memang bukan milik semua orang. Hanya bagi mereka yang sadar untuk terus membangun kekuatan rantai nilai inovasinya (Febransyah, 2016:14).

Pilihan pembangunan yang didasarkan Indonesia sentris merupakan pilihan kebijakan publik yang dilakukan pemerintah, hal ini sejalan dengan Dye (1981:1) yang mendefinisikan kebijakan publik sebagai apapun pilihan pemerintah untuk melakukan atau tidak melakukan sesuatu. Bahwa hal yang paling pokok dari suatu kebijakan adalah adanya tujuan, sasaran, atau kehendak. 
Di samping itu. pembangunan yang dilakukan di tatanan masyarakat di Indonesia mengandung makna adanya keterkaitan yang tidak hanya secara ekologis dan ekonomi, tetapi juga secara sosiologis, terutama pada tingkat pengambilan keputusan. Beragam keterkaitan tersebut berhubungan secara fungsional, karena dipandang sebagai suatu sistem kelembagaan lokal yang berpengaruh pada kehidupan masyarakat (Nasdian, 2014:221). Pembangunan dengan menitikberatkan pada infrastruktur yang dilakukan di seluruh pelosok tanah air secara bersama sama. Dengan infrastruktur yang terbangun merata, maka masyarakat dapat memenuhi kebutuhannya.

Pembangunan secara menyeluruh masih memiliki kekurangan, karena menggunakan pinjaman luar negeri dalam jumlah yang sangat banyak yang membebani Anggaran Pendapatan Belanja Negara (APBN). Dengan pembangunan infrastruktur yang mahal, maka ada sisi lain yang dikorbankan untuk sementara waktu, yaitu daya beli masyarakat yang saat ini menurun dan tidak bisa dibantu lagi dengan Bantuan Langsung Tunai (BLT). Pemerintah memfokuskan pada pembangunan infrastruktur, seperti jalan tol, bandara, pasar, dan lain-lain. Tidak ada masyarakat yang dirugikan dalam pelaksanaan pembangunan secara merata ini. Semua rakyat bisa menikmati dengan bahagia. Masyarakat Papua yang selama ini membeli bensin dengan harga mahal akan mendapatkan harga yang sama seperti membeli bensin di Jawa. Pemerintah telah mempertimbangkan dengan matang mengenai hal-hal yang harus dilakukan.

Pembangunan dengan model Indonesia Centris juga mengedepankan pada sila kelima Pancasila, yaitu keadilan sosial bagi seluruh rakyat Indonesia. Mengingat rakyat Indonesia dari Sabang hingga Merauke, maka pembangunan yang dilakukan juga harus dari Sabang sampai Merauke. Tidak ada lagi kecemburuan sesama bangsa dan antardaerah. Semuanya bisa berkompetensi secara sehat apabila ada investor mau menginvestasikan modalnya. Inilah inovasi yang tentunya diawali dengan mimpi yang kemudian dibuktikan dengan pengejawantahan dalam Nawacita.

Satu hal yang perlu dicermati dan disiasati dengan baik adalah bagaimana keuangan negara mencukupi untuk bisa membangun dengan pola Indonesia Centris ini. Mengingat jumlah APBN yang tebatas, maka perlu dilakukan pengkajian secara mendalam supaya pembangunan yang sudah direncanakan dapat dijalankan dengan baik dan memenuhi harapan rakyat. Pemerintah harus melakukan terobosan dan inovasi seperti yang dilakukan dalam program Tax Amnesty, di mana dana reptriasi bisa masuk ke Indonesia dan membantu dalam program pembangunan infrastruktur. APBN haru ditingkatkan melalui berbagai program, seperti peningkatan penerimaan dari wajib pajak dan membuka peluang usaha dan investasi bagi negara lain untuk bisa masuk dan melakukan pembangunan infrastruktur yang membuka lapangan kerja baru. Pajak sangat dibutuhkan dalam suasana kekurangan dana dalam pembangunan. Dengan keuangan yang memadai, maka pembangunan di seluruh tanah air bisa dilakukan dengan baik. Bisa mewujudkan pembangunan manusia seutuhnya, baik lahir maupun batin, melalui pembangunan karakter yang sering disebut dengan revolusi mental.

Amandemen perubahan UUD 1945 kembali dilakukan oleh penyelenggara negara untuk menuju kesempurnaan dalam menjalankan roda pemerintahan. Oleh karena itu, pemerintah sudah mulai menyadari pentingnya Garis Besar Haluan Negara (GBHN) sebagai arah pembangunan jangka panjang yang 
berkesinambungan. Pada masa Orde Baru, GBHN dijalankan dengan baik dan sukses. Rupanya dengan pengalaman pada masa Orde Baru tersebut, pemerintah sekarang akan mengamandemen kembali UUD 1945 dengan memasukkan kembali GBHN.

\section{Kesimpulan}

Pembangunan yang dilakukan secara Indonesia Centris akan memberikan kemakmuran yang merata di seluruh tanah air, karena pemerinah tidak lagi mengotakkan dan menggolongkan pembangunan per provinsi, tetapi yang mendasari kebijakan ini adalah sila kelima Pancasila. Suatu kemakmuran dan kesejahteraan akan terpenuhi manakala setiap warga Indonesia berpartisipasi dalam pembangunan, sehingga mengubah pola dan gaya hidup yang selama ini tertinggal dan bisa melihat perubahan positif dari hasil pembangunan. Inovasi dan pembaruan sangat diperlukan untuk mengubah peta jalan pembangunan bangsa Indonesia yang berkelanjutan dengan tetap mengedepankan dan menghormati kearifan lokal dan HAM. Dengan terobosan yang demikian, maka masyarakat yang adil dan makmur berdasarkan Pancasila dalam kebhinekaan dan kemajemukan bisa terwujud dengan baik dan saling menghormati keberagaman dalam persatuan.

\section{Daftar Pustaka}

Bovaird, T. dan Loffler, E., 2003. Public Management and Goverance. London: Routledge.

Budiono, 2016. Ekonomi Indonesia Dalam Lintasan Sejarah. Jakarta: PT Mizan Pustaka.

Dye, T. R., 1981. Understanding Public Policy, Fourth Edition. New Jersey: Prentice Hall, Inc.

Febriansyah, 2016. Belajar Inovasi Untuk Menang. Jakarta: PT Grafika Mardi Yuana.

Martono, 2014. Sosiologi Perubahan Sosial. Jakarta: Rajawali Press.

Nasdian, 2014. Pengembangan Masyarakat. Jakarta: Yayasan Pustaka Obor Indonesia.

Parsons, W., 2001. Public Policy: Pengantar Teori dan Praktik Analisis Kebijakan. Jakarta: Prenada Media.

Sumaryadi, 2005. Perencanaan Pembangunan Daerah Otonom \& Pemberdayaan Masyarakat. Jakarta: Citra Utama.

Winarno, B., 2014. Kebijakan Publik, Teori, Proses dan Studi Kasus. Center of Academic Publishing Service.

Winarno, B., 2002. Teori dan Proses Kebijakan Publik. Yogyakarta: Media Pressindo. 